\title{
Qualidade Microbiológica e Importância da Pesquisa de Estafilococos Coagulase Positiva em Couves Minimamente Processadas, Comercializadas no Município de Campo Mourão
}

Marcia R. F. Geraldo Perdoncini (I), Anderson Clayton Silva (I), Gisele Cristina Pante (I)

(I) UTFPR - Universidade Tecnologica Federal do ParanáTecnologica Federal do Paraná (Via Rosalina Maria dos Santos, 1233 cep 87301-899 Campo Mourão - Pr)

\section{Resumo}

As hortaliças podem ser contaminadas quando frescas ou após processamento. Os vegetais minimamente processados não são considerados livres de microrganismos. Durante o processamento, os vegetais inteiros são lavados com água contendo cloro entre 50 e 200 ppm, e depois cortados e embalados. Enquanto a lavagem reduz o número de microrganismos, a realização do corte tem a capacidade de recontaminar o produto. Além disso, os vegetais recém cortados apresentam uma elevada umidade, maior quantidade de nutrientes simples e maior superfície de contato que os vegetais não cortados, fazendo com que os produtos minimamente processados se tornem mais susceptíveis ao crescimento microbiano. Este trabalho teve como objetivo avaliar as condições microbiológicas de amostras de couve minimamente processadas em relação a coliformes a $35^{\circ} \mathrm{C}$ e termotolerantes, Salmonella sp, estafilococos coagulase positiva, microrganismos mesófilos aeróbios estritos e facultativos e psicrotróficos. Amostras de couve minimamente processada, comercializadas em bandejas de isopor, embaladas com filme plástico ou sacos de polietileno armazenada sob-refrigeração em torno de $5^{\circ} \mathrm{C}$, foram adquiridas em supermercados de Campo Mourão, Paraná. Foram analisadas 27 amostras durante os meses de maio a agosto de 2013. Todas as análises foram realizadas segundo metodologia descrita na Instrução Normativa $\mathrm{N}^{\circ}$

\footnotetext{
Referência:

Marcia R. F. Geraldo Perdoncini, Anderson Clayton Silva, Gisele Cristina Pante.Qualidade Microbiológica e Importância da Pesquisa de Estafilococos Coagulase Positiva em Couves Minimamente Processadas, Comercializadas no Município de Campo Mourão. In: Anais do 12 Congresso Latinoamericano de Microbiologia e Higiene de Alimentos - MICROAL 2014 [= Blucher Food Science Proceedings, num.1, vol.1]. São Paulo: Editora Blucher, 2014.

DOI $10.5151 /$ foodsci-microal-110
} 
62, de 26 de agosto de 2003. Salmonella sp e estafilococos coagulase positiva também foram analisadas por métodos rápidos. Das amostras analisadas nenhuma apresentou presença de Salmonella sp. Para coliformes termotolerantes, $33 \%$ das amostras apresentaram valores acima dos padrões permitidos pela legislação segundo RDC No 12 de Janeiro de 2001. Para a pesquisa de estafilococos coagulase positiva $78 \%$ das amostras apresentaram valores elevados comparado a resultados encontrados por outros autores. As contagens de microrganismos mesófilos aeróbios estritos e facultativos e psicrotróficos encontraram-se dentro do limite aceitável conforme estudos semelhantes. Os resultados mostram a importância da pesquisa de estafilococos coagulase positiva em vegetais minimamente processados, o qual indica falhas na manipulação desses alimentos e a necessidade dos cuidados para se evitar recontaminação durante $o$ processamento de desses vegetais.

Palavras-Chave: couves minimamente processadas, qualidade microbiologica, estafilococos coagulase positiva

Agência de Fomento: 